present available are useful only in explaining the fundamental principles of television or of illustrating the historical development of the subject, which dates back some sixty years. With the object of temporarily filling this gap in the literature, the issue of the Wireless World of March 8 incorporated as a supplement a "Television Guide", comprising a 30-page booklet giving a simple explanation of the subject adequately illustrated by diagrams and photographs. This guide assumes a knowledge of electricity and the principles of radio communication on the part of the reader; the principles involved in television are clearly explained, together with the use and limitations of mechanical scanning systems. The manner in which the cathode ray oscillograph tube has been introduced into the art is described, with the resulting accelerated progress towards high definition television. The most recent developments of picture transmission technique are dealt with, including Zworykin's iconoscope and Farnsworth's image dissector as alternative scanning systems, and the use of the intermediate cinematograph film for the broadeasting of current events. The trend of this supplement to the Wireless World is definitely to explain the principles of the subject to the future owner of a television receiver, and as such, it may be said to form a useful appendix to the report of the Postmaster-General's Committee.

\section{Safe Passing Speeds for Motor-Cars}

Every driver of a motor-car who desires to pass another car going in the same direction has to consider the problem of whether it is possible or not. Apart from the question of whether there is another car coming round the bend of the road in the opposite direction, he has to consider whether there is sufficient clear space ahead. According to a Science Service message, Dr. H. C. Dickinson, of the U.S. Bureau of Standards, has completed tests to find out how much clear space is necessary. Assuming a speed limit of 45 miles an hour and that cars travelling 50 miles an hour are tolerated, he finds that a distance of $900 \mathrm{ft}$. is required for safe clearance. The time required to pass on a level road depends only on their relative speed of five miles an hour, and is nearly six seconds. If the vehicle ahead is moving at 20 miles an hour the distance required is $650 \mathrm{ft}$., $200 \mathrm{ft}$. being required for the actual passing and $450 \mathrm{ft}$. being the necessary allowance for a car approaching at 50 miles an hour. The Highway Research Board of the U.S. National Research Council points out that, considering the number of roads in the country where clear stretches of $900 \mathrm{ft}$. are rare, there is often a serious risk when passing another car at high speed. In mountainous country, winding and hilly roads would come under this category. Dr. Dickinson's figures apply to a car passing only one car ahead; when long lines of cars 'pile up' on the road, greater distances are required for safe passing.

\section{Library of the University of the Witwatersrand}

THE University of the Witwatersrand was the scene of a disastrous fire three years ago, when the greater part of its library, including the Gubbins and the
Hoernle anthropological collections, was destroyed. Appeals for help led to a very substantial measure of replacement, gratefully acknowledged by the University in a letter to the Appeal Committee in London, which has now issued its final report. In this, the chairman, Sir Frank Heath, observes that, while it is impossible to mention individually all the contributors, including learned, technical and scientific societies in England and America, universities and colleges throughout the British Isles and Canada, industrial firms, industrial research associations, British Government departments and the leading missionary societies having stations in South Africa, very special thanks are due to the British Association, the London School of Economics and Imperial Chemical Industries, Ltd. New College, Oxford, and the Imperial College of Science and Technology helped to defray expenses of collection, packing, transportation and insurance. The Union-Castle Steamship Co. undertook the transport of books at a discount of 50 per cent on the ordinary freight charges, and the High Commissioner for the Union of South Africa lent an office rent-free. The Universities Bureau of the British Empire placed its council room at the disposal of the Committee for its meetings. Besides books and manuseripts, a large quantity of pictures, coins, etc., was collected which will form the nucleus of a Johannesburg municipal museum. Some 32,000 volumes in all were dispatched by the Committee.

\section{A Giant Tortoise}

A FINE specimen of Porter's black tortoise (Testudo nigrita) has just been added to the Tortoise House of the Gardens of the Zoological Society of London. This is one of several species attaining a relatively gigantic size, which, a hundred and fifty years ago, swarmed in the Galapagos Islands, the Mascarene Islands, the Aldabras and the Seychelles. Then they attracted the attention of mariners, who forthwith began to visit these islands and carry away their victims by the boat-load. Exploitation of this kind, whether of tortoises or whales, inevitably ends in extermination. On only a very few of these islands are any survivors to be found to-day. But it fortunately happened that many species were taken to other islands, where they bred. This was the case with the species which has just come to the Zoo. For Capt. Porter, on his voyage from the Galapagos, in 1813, distributed several young tortoises from his stock among the chiefs of the Fiji Islands. Many of these escaped, and bred there. The great size of these animals is shown by the fact that the shell of the various species ranged from three to six and a half feet along the curve. Until its death, a few years ago, the largest living tortoise known was owned by Lord Rothschild. This was a specimen of Testudo daudini, of the South Island of Aldabra, taken, with six others, in 1895. The length of the shell was 55 in., or $67 \frac{1}{2}$ in. over the curve. The total weight was $560 \mathrm{lb}$. But even this was a mere pigmy compared with the extinct fossil tortoise (Colos sochelys atlas) from the Lower Pliocene of the Siwalik Hills, India, which had a shell eight feet in length. 